\title{
ANALISIS KEMAMPUAN MAHASISWA PROGRAM STUDI MATEMATIKA DALAM MEMBUAT BAHAN AJAR DENGAN PERANGKAT LUNAK GEOGEBRA MELALUI PEMBELAJARAN BERBASIS PROYEK
}

\author{
Sendi Ramdhani \\ FKIP Universitas Suryakancana Cianjur \\ sendiramdhani@yahoo.com
}

ABSTRAK

Penelitian ini bertujuan untuk mengetahui kemampuan mahasiswa program studi matematika dalam membuat bahan ajar dengan perangkat lunak geogebra melalui pembelajaran berbasis proyek. Bentuk penelitian yang digunakan dalam penelitian ini kualitatif yang mendeskripsikan kemampuan mahasiswa program studi matematika dalam membuat bahan ajar dengan perangkat lunak geogebra melalui pembelajaran berbasis proyek. Rangkaian kegiatan penelitian ini adalah observasi langsung dan catatan faktual perihal proses pembelajaran berbasis proyek dan kemampuan mahasiswa dalam membuat bahan ajar dengan perangkat lunak Geogebra berdasarkan penilaian dosen dan guru. Subjek penelitian adalah mahasiswa program studi pendidikan matematika sebagai calon guru. Teknik pengumpulan data adalah dengan 1) penilaian dosen dan 2) penilaian guru. Hasil penelitian dapat dipaparkan bahwa Kemampuan mahasiswa program studi pendidikan matematika dalam membuat bahan ajar dengan perangkat lunak Geogebra melalui pembelajaran berbasis proyek nilai 78 dan mengindikasikan bahwa Kemampuan mahasiswa program studi pendidikan matematika dalam membuat bahan ajar dengan perangkat lunak Geogebra pada kategori tinggi.

Kata kunci : pembelajaran berbasis proyek, bahan ajar, geogebra

\section{Pendahuluan}

Undang-undang (UU) No.20 Tahun 2003 tentang Sistem Pendidikan Nasional Pasal 40 Ayat 2a menyatakan bahwa pendidik dan tenaga kependidikan berkewajiban menciptakan suasana pendidikan yang bermakna, menyenangkan, kreatif, dinamis, dan dialogis. Suasana pendidikan yang dimaksud harus tergambar dalam pelaksanaan pembelajaran di kelas. Pembelajaran di kelas harus dirancang dan dibuat sehingga mampu menciptakan suasana pendidikan yang dimaksud.

Bahan ajar, lembar kerja, media, alat bantu belajar merupakan bagian penting dalam pembelajaran. Pedoman mata pelajaran matematika kurikulum 2013 menuntut pengembangan, perumusan, penyusunan, dan penggunaan sumber belajar (bahan ajar, lembar kerja, media, alat bantu belajar lainnya) yang lebih inovatif, kreatif, efektif, efisien dan kontekstual sesuai dengan kondisi, kebutuhan, kapasitas, karakteristik, dan sosial budaya daerah, sekolah/satuan pendidikan dan peserta didik.

$$
\text { Teknologi komputer dapat }
$$

digunakan untuk memudahkan dan efektivitas pembelajaran matematika suatu kompetensi tertentu, guru dapat memanfaatan berbagai bahan dan sumber belajar, misalnya, untuk menyajikan dan meringkas data, menggambar grafik fungsi aljabar maupun trigonometri, mengkonstruk bangun-bangun geometri.

Penggunaan teknologi informasi dan komunikasi dalam pembelajaran merupakan salah satu prinsip dalam penyusunan rencana pembelajaran. Hal ini tercantum dalam Permendikbud No. 65 Tahun 2013 Tentang Standar Proses. Menurut Kusumah (2011) guru harus mengenal teknologi instruksional yang memberi alat perhitungan, grafik dan simbolik untuk tujuan eksplorasi, investigasi, inkuiri, generalisasi, dan penerapan materi pelajaran. Teknologi ini harus disertakan dalam kegiatan instruksional dan harus mampu memberi siswa dengan ilham dan pemahaman. 
Penggunaan teknologi dapat meningkatkan dan memperluas pembelajaran yang memungkinkan siswa merancang eksplorasinya sendiri dan menyusun pengetahuan atau ide sendiri. Penggunaan teknologi seperti media interaktif pembelajaran matematika akan membuat matematika yang konsepkonsepnya abstrak menjadi lebih nyata karena bisa ditampilkan dalam bentuk visualisasi. Bagi para siswa, visualisasi akan lebih menyenangkan dan memudahkan dalam pembelajaran matematika.

Teknologi yang banyak digunakan dalam pembelajaran matematika adalah komputer. Salah satu perangkat lunak komputer yang dapat dimanfaatkan dalam pembelajaran matematika adalah perangkat lunak GeoGebra. Dengan beragam fasiltas yang dimiliki, GeoGebra dapat dimanfaatkan sebagai media pembelajaran matematika untuk mendemonstrasikan atau memvisualisasikan konsep-konsep matematis serta sebagai alat bantu untuk mengkonstruksi konsep-konsep matematis (Mahmudi, 2011).

Kemampuan mahasiswa programs studi matematika sebagai calon guru dalam membuat bahan ajar dengan teknologi komputer yang salah satunya dengan perangkat lunak Geogebra merupakan suatu keharusan sehingga ketika mereka menjadi guru mampu merancang dan membuat pembelajaran yang lebih inovatif, kreatif, efektif, efisien dan kontekstual. Sebagai upaya untuk meningkatkan kemampuan tersebut harus disusun metode perkuliahan yang memiliki tujuan agar mahasiswa calon guru mampu merancang dan membuat bahan ajar dengan teknologi komputer. Salah satu metode perkuliahan yang memungkinkan adalah pembelajaran berbasis proyek.

$\begin{array}{lrr}\text { Pembelajaran Berbasis } & \text { Proyek } \\ \text { merupakan metode } \text { belajar } & \text { yang } \\ \text { menggunakan masalah sebagai langkah } & \text { lan } \\ \text { awal dalam mengumpulkan } & \text { dan } \\ \text { mengintegrasikan pengetahuan } & \text { baru } \\ \text { berdasarkan pengalamannya dalam }\end{array}$

beraktifitas secara nyata. Pembelajaran Berbasis Proyek dirancang untuk digunakan pada permasalahan komplek yang diperlukan mahasiswa calon guru dalam melakukan insvestigasi dan memahaminya. Mahasiswa calon guru dihadapkan dengan permasalahan untuk membuat bahan ajar yang inovatif, kreatif, efektif, efisien dan kontekstual.

Penelitian ini bertujuan untuk menganalisis dan mendeskripsikan "Analisis Kemampuan Mahasiswa Program Studi Matematika dalam Membuat Bahan Ajar dengan Perangkat Lunak Geogebra melalui Pembelajaran Berbasis Proyek"

\section{KAJIAN LITERATUR}

\section{Bahan Ajar}

Bahan ajar merupakan informasi, alat dan teks yang diperlukan guru atau instruktur untuk perencanaan dan penelaahan implementasi pembelajaran. Menurut Syah (Rahmi, 2013) Bahan pembelajaran merupakan salah satu sumber belajar yang berisikan pesan dalam bentuk-bentuk, konsep, prinsip, definisi, kontes, data, fakta, proses, nilai, dan keterampilan.

Bahan ajar merupakan segala bahan (baik informasdi, alat maupu teks) yang disusun secara sistematis yang menampilkan sosok utuh dari kompetensi yang akan dikuasai oleh peserta didik yang digunakan dalam proses pembelajaran dengan tujuan perencanaan dan penelaahan implementasi pembelajaran. Misalnya buku pelajaran, modul, bahan ajar audio, bahan ajar interaktif dan sebagainya (Prastowo, 2014)

Menurut Hamdani (2011), ruang lingkup bahan ajar meliputi

1. Judul, mata pelajaran, standar kompetensi, kompetensi dasar, indikator dan tempat

2. Petunjuk belajar (Petunjuk siswa/ guru), yaitu alur atau langkah yang harus dilakukan untuk mempermudah pembelajaran.

3. Kompetensi yang akan dicapai, yaitu nilai atau konsep dasar yang harus 
dikuasai oleh siswa dalam setiap materi pembelajaran. Hal ini terkait dengan materi selanjutnya karena semua ini berkesinambungan.

4. Kontent atau isi materi pembelajaran, yaitu inti dari pembelajaran tersebut yang harus dipelajari sesuai dengan kompetensi dasar yang telah dimiliki.

5. Informasi pendukung Info atau sumber berita yang lain yang mendukung terhadap materi pembelajaran.

6. Latihan-latihan, yang terdapat pada akhir subbab, akhir bab, akhir semester 1 dan semester 2 .

7. Petunjuk kerja, dapat berupa Lembar Kerja (LK)

8. Evaluasi

9. Respon atau balikan terhadap hasil evaluasi

Bahan ajar terdapat dua bentuk (Hernawan Dkk, 2010), yaitu:

1. Bahan ajar yang didesain lengkap, artinya bahan ajar yang memuat semua komponen pembelajaran secara utuh, meliputi: tujuan pembelajaran atau kompetensi yang harus dicapai, kegiatan belajar yang harus dilakukan siswa, materi pembelajaran yang disusun secara sistematis, ilustrasi/media dan alat peraga, latihan dan tugas, evaluasi, dan umpan balik.

2. Bahan ajar yang didesain tidak lengkap, artinya bahan ajar yang didesain bentuk terbatas, seperti dalam bentuk komponen pembelajaran yang terbatasm seperti dalam bentuk sumber belajar, media pembelajaran atau alat peraga yang digunakan sebagai alat bantu ketika tenaga pendidik dan siswa melaksanakan kegiatan pembelajaran.

Adapun jenis bahan ajar dapat dikelompokkan, sebagai berikut:

1. Printed Materials
a. Handiout
b. Buku Pelajaran
c. Modul
d. Programed Materials

2. Electronic Materials
a. CD interaktif
b. TV
c. Radio

\section{Pedoman Pembuatan Bahan Ajar dengan Geogebra}

Pedoman desain bahan ajar interaktif dengan Geogebra adalah hasil dari evaluasi formatif yang diciptakan oleh guru-guru di kelas NSF MSP selama musim gugur 2006 dan musim semi 2007. Panduan ini berdasarkan pada prinsipprinsip desain untuk multimedia pembelajaran dinyatakan oleh Clark dan Mayer (Judith and Hohenwarter, 2013)

1. Pedoman Desain 1: Layout Bahan Ajar Interaktif

a. Menghindari Scrolling

Seluruh bahan ajar harus muat di satu layar. Siswa tidak harus menggeser-geser gambar interaktif. Ukuran layar kira-kira $1024 \times 768$ atau $1280 \times 1024$ piksel. JIka menggunakan editor HTML seperti NVU dapat menggunakan tabel untuk mengatur teks, gambar, dan gambar-gambar interaktif sehingga termuat dalam satu layar. Jika hal ini tidak mungkin, pertimbangkan untuk membuat bahan ajar interaktif menjadi beberapa halaman.

b. Penjelasan Singkat

Pada awal bahan ajar interaktif harus diberikan penjelasan tentang isinya. Buat teks singkat (tidak lebih dari satu atau dua kalimat) dan menuliskannya dengan gaya pribadi.

c. Memuat Tugas

Penambahan pertanyaan atau tugas untuk memastikan bahwa siswa menggunakan bahan ajar interaktif sesuai dengan tujuan yang ingin dicapai. Tempatkan tugas-tugas ini dekat dengan applet interaktif (misalnya langsung di bawahnya). Jangan menggunakan lebih dari tiga atau empat pertanyaan/ tugas untuk menghindari scrolling. Jika memiliki lebih banyak tugas, pertimbangkan untuk memecah bahan ajar menjadi beberapa halaman.

d. Menghindari Gangguan 
Pastikan bahwa lembar kerja dinamis hanya berisi objek-objek yang relevan dengan tujuan. Hindari menggunakan background yang tidak perlu atau gambar yang hanya dekoratif saja, atau musik pada halaman web agar tidak mengalihkan perhatian siswa terhadap pencapaian tujuan.

2. Pedoman Desain 2: Gambar Dinamis

a. Interaktif

Buat sebanyak mungkin bentuk interaktif dalam gambar dinamis. Sebagai aturan praktis, semua objek harus terlihat bergerak atau berubah dengan beberapa cara. Gambar dinamis harus menyediakan banyak kebebasan untuk mengeksplorasi hubungan objek-objek matematika dan dalam menemukan konsep-konsep matematika.

b. Mudah Digunakan

Buatlah gambar dinamis semudah mungkin digunakan. Jika suatu objek dapat dipindahkan atau diubah, cobalah untuk membuat ini lebih jelas, misalnya semua titik yang bergerak diberi warna merah atau lebih besar ukurannya. Jika tidak ingin objek berubah, jadikan objek tetap (misalnya teks, fungsi atau posisi slider) sehingga tidak dapat dipindahkan secara tidak sengaja.

c. Ukuran

Gambar dinamis harus cukup besar yang memungkinkan semua manipulasi yang dimaksudkan, tetapi cukup kecil untuk muat di satu layar dan masih meninggalkan ruang yang cukup untuk penjelasan dan pertanyaan pada halaman web sekitarnya.

d. Gunakan Teks Dinamis

Teks dinamis, seperti panjang ruas garis yang berubah, harus ditempatkan dekat dengan objek yang sesuai pada applet.

e. Hindari Teks Statis

Terlalu banyak teks statis dapat dengan mudah mengacaukan applet interaktif. Tetapi, teks statis dapat digunakan untuk penjelasan atau pertanyaan pada halaman web yang mencakup gambar dinamis.

f. Tampilan Pertama

Ketika bahan ajar dibuka harus dapat membaca semua label dan informasi penting. Sebagai contoh, sebuah label titik tidak boleh dilintasi garis.

3. Pedoman Desain 3: Penjelasan dan Tugas

a. Pendek, Jelas dan Gaya Pribadi

Tulislah penjelasan dan pertanyaan dalam gaya singkat, jelas dan bentuk percakapan.

b. Jumlah Pertanyaan Sedikit

Batasi jumlah pertanyaan atau tugas per bahan ajar untuk tiga atau empat untuk menghindari scrolling. Jika ingin mengajukan lebih banyak pertanyaan, buat halaman baru.

c. Gunakan Pertanyaan Spesifik

Hindari pertanyaan umum seperti 'Apakah $\mathrm{x}$ selalu benar? " dan buatlah pertanyaan sebagai hasil dari apa yang dilakukan siswa, misalnya 'Apa yang terjadi pada $X$ ketika Anda pindahkan Y?"..

d. Mengacu Pada Applet Sendiri

Teks Anda harus mendukung penggunaan applet interaktif. Sebagai contoh, cobalah untuk menjelaskan istilah baru dengan mengacu pada applet sendiri daripada menggunakan definisi tekstual lain. Selain itu, dapat mewarnai kata kunci tertentu agar cocok dengan gaya format objek yang siswa lihat. Hal ini membuat teks lebih mudah dibaca dan membantu siswa untuk menemukan representasi yang sesuai dari objek yang sama.

e. Siswa adalah Pembelajar

Jika ingin memberikan informasi bagi para pendidik lainnya (misalnya rencana pelajaran, solusi) buatlah dalam dokumen terpisah (misalnya halaman web, pdfdokumen). Siswa-siswa tidak boleh terganggu atau bingung dengan informasi tersebut.

f. Demonstrasi Gambar

Jika gambar interaktif dimaksudkan untuk presentasi, mungkin lebih baik untuk tidak memasukan tugas atau pertanyaan pada halaman web. Jika memasukan teks, itu harus dipahami bagi siswa juga.

\section{METODE PENELITIAN}

Pada penelitian ini peneliti ingin mengetahui dan menganalisa kemampuan mahasiswa program studi pendidikan matematika dalam membuat bahan ajar 
dengan perangkat lunak Geogebra melalui Pembelajaran Berbasis Proyek. Rangkaian kegiatan penelitian ini adalah observasi langsung dan catatan faktual perihal proses pembelajaran berbasis proyek dan kemampuan mahasiswa dalam membuat bahan ajar dengan perangkat lunak Geogebra

Penelitian ini dilakukan ini dilakukan pada semester ganjil tahun akademik 2014/2015 di FKIP Universitas Suryakancan Cianjur. Subjek penelitiannya adalah mahasiswa program studi pendidikan matematika semester 3 sejumlah 62 mahasiswa yang dibagi menjadi 11 kelompok. Adapun instrumen dalam penelitian ini adalah: 1) Bahan Ajar dengan Perangkat Lunak Geogebra, 2) Penilaian Dosen, dan 3) Penilaian Guru.

Bahan ajar hasil pekerjaan siswa dinilai oleh dosen berkaitan dengan kelengkapan bahan ajar berdasarkan pedoman desain pembuatan. Selanjutnya, bahan ajar diujicobakan ke sekolah untuk mengetahui penilaian guru matematika.

Setelah data dari lapangan terkumpul maka peneliti akan mengolah dan menganalisis data tersebut dengan menggunakan analisis secara deskriptifkualitatif, tanpa menggunakan teknik kuantitatif. Analisis deskriptif-kualitatif merupakan suatu teknik yang menggambarkan dan menginterpretasikan arti data-data yang telah terkumpul dengan memberikan perhatian dan merekam sebanyak mungkin aspek situasi yang diteliti pada saat itu, sehingga memperoleh gambaran secara umum dan menyeluruh tentang keadaan sebenarnya.

Pengkategorian kualitas kemampuan mahasiswa, peneliti menggunakan penilaian skala lima dan Tabel konversi sebagai berikut:

$\begin{array}{ll}90 \% \leq A \leq 100 \% & \text { Sangat Tinggi } \\ 75 \% \leq B<90 \% & \text { Tinggi } \\ 55 \% \leq C<75 \% & \text { Cukup } \\ 40 \% \leq D<55 \% & \text { Rendah } \\ 00 \% \leq E<40 \% & \end{array}$

\section{HASIL PENELITIAN}

Di awal perkuliahan para mahasiswa dibentuk menjadi beberapa kelompok dan diberikan tugas sebagai sebuah proyek membuat bahan ajar dengan perangkat lunak geogebra. Mahasiswa ditugaskan melakukan eksplorasi untuk menghasilkan bahan ajar dengan perangkat lunak Geogebra. Langkah awal, mahasiswa menentukan tujuan pembelajaran dan materi yang akan termuat dalam bahan ajar dengan mengeksplorasi kurikulum sekolah, baik Sekolah Menengah Pertama (SMP), maupun Sekolah Menengah Atas (SMA).

Mahasiswa dihadapkan dengan permasalahan bagaimana membuat bahan ajar dengan perangkat lunak Geogebra yang inovatif, kreatif, efektif, efisien dan kontekstual sesuai dengan kondisi, kebutuhan, kapasitas, karakteristik sekolah/satuan pendidikan dan peserta didik. Mahasiswa mengumpulkan dan mengintegrasikan pengetahuan tentang perangkat lunak Geogebra dan pembelajaran matematika. Mahasiswa dituntut membuat keputusan tentang sebuah kerangka kerja masing-masing, mendesain proses untuk menentukan bahan ajar dengan perangkat lunak Geogebra, dan secara kolaboratif mengakses dan mengelola informasi.

Dosen sebagai peneliti menuntun dan membimbing mahasiswa dalam sebuah proyek kolaboratif yang mengintegrasikan berbagai subjek (materi). Proses evaluasi dijalankan secara kontinyu, mahasiswa bersama dosen secara berkala melakukan refleksi atas aktivitas yang sudah dijalankan, dan bahan ajar dengan perangkat lunak Geogebra sebagai hasil aktivitas belajar akan dievaluasi secara kualitatif. Secara umum Peran dosen dalam proses pembelajaran berbasis proyek sebaiknya sebagai fasilitator, pelatih, penasehat dan perantara untuk mendapatkan hasil yang optimal (Suherman, 1990) asi, kreasi dan 
Adapun hasil bahan ajar dengan perangkat lunak Geogebra sebagai produk aktivitas mahasiswa sangat beragam dari segi materi dan tingkat satuan pendidikan.

Tabel 1. Tampilan Hasil Bahan Ajar Dengan Perangkat Lunak Geogebra

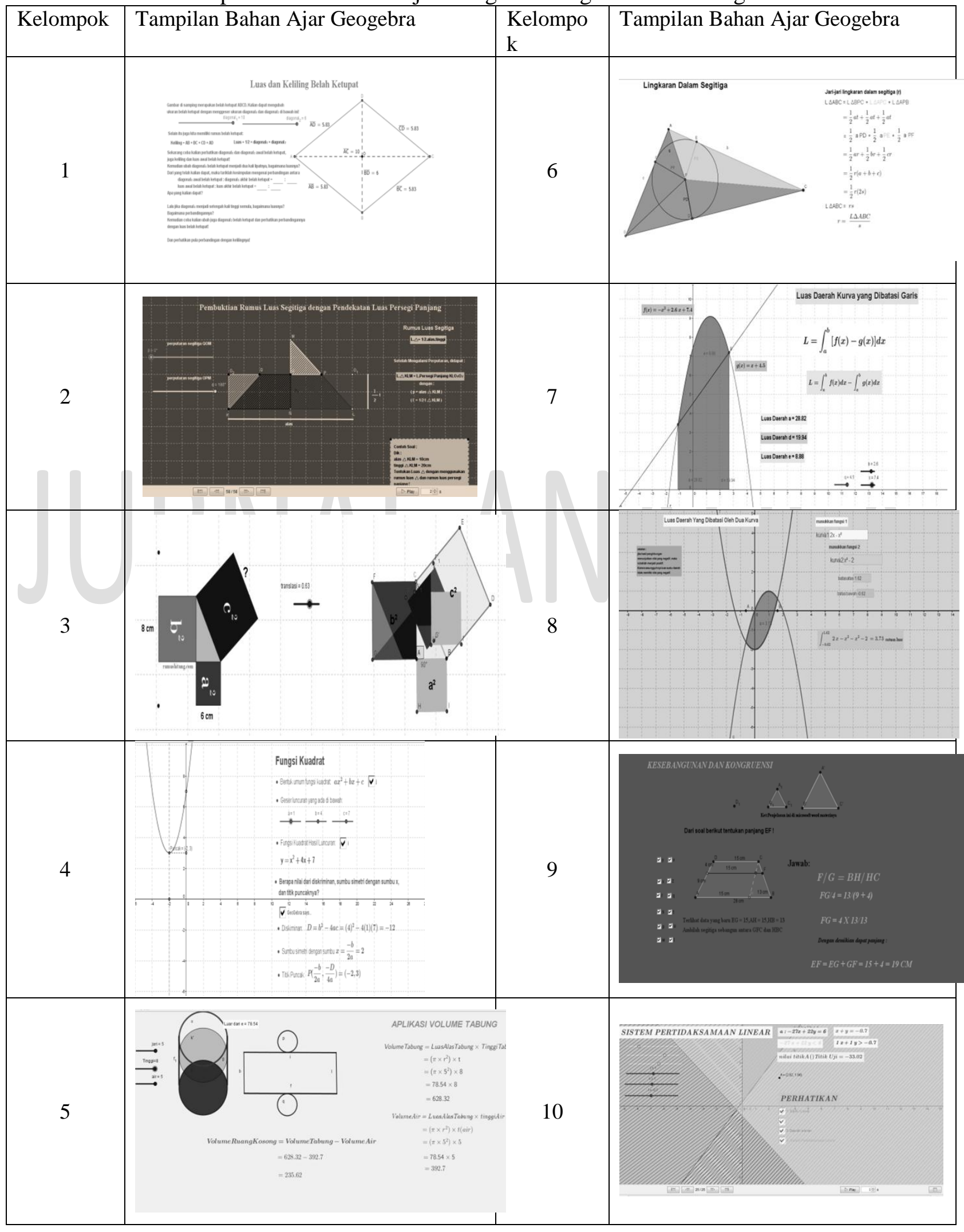
ajar dengan perangkat lunak Geogebra pada setiap kelompoknya.

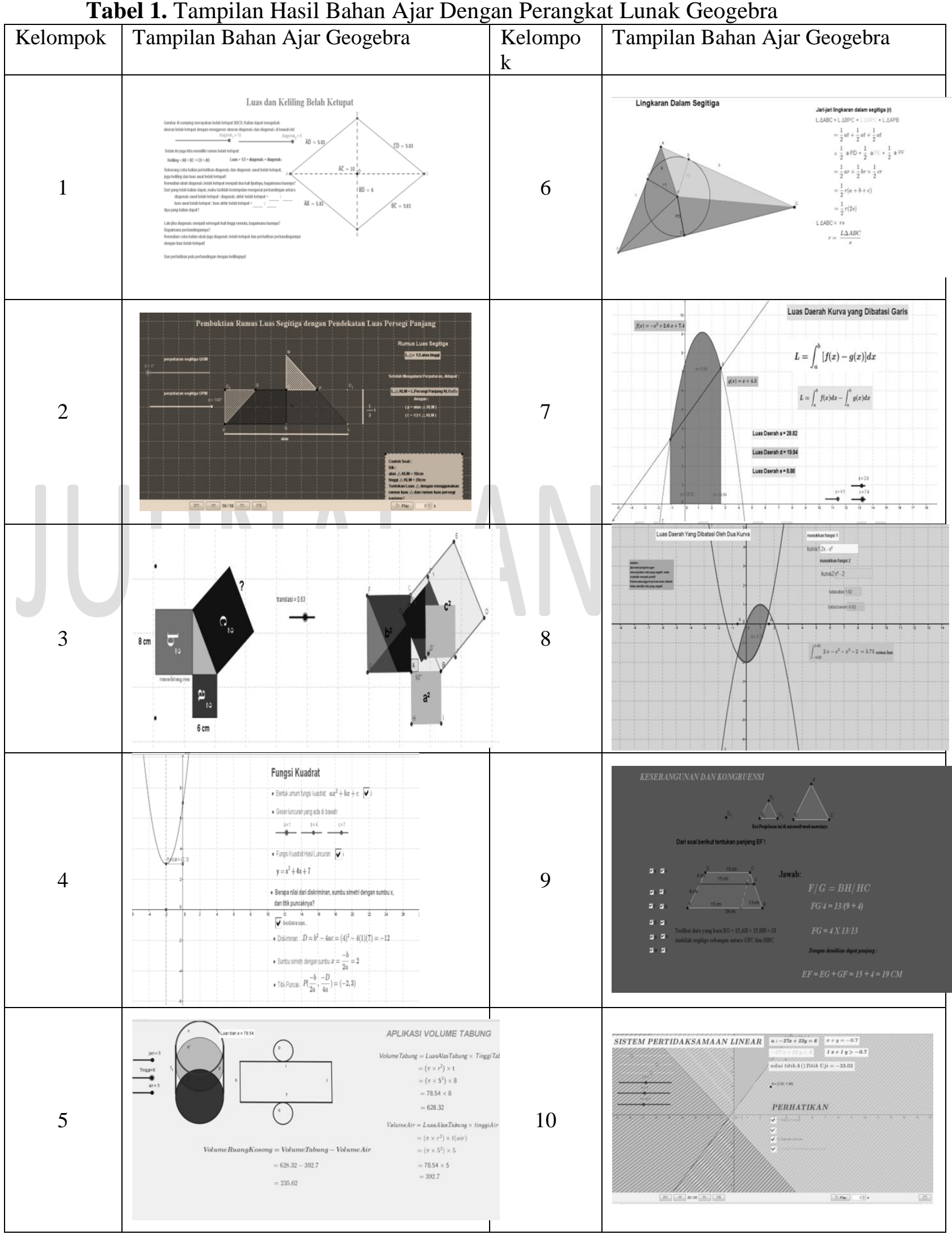

Jurnal Analisa Volume II Nomor 3 September 201632 


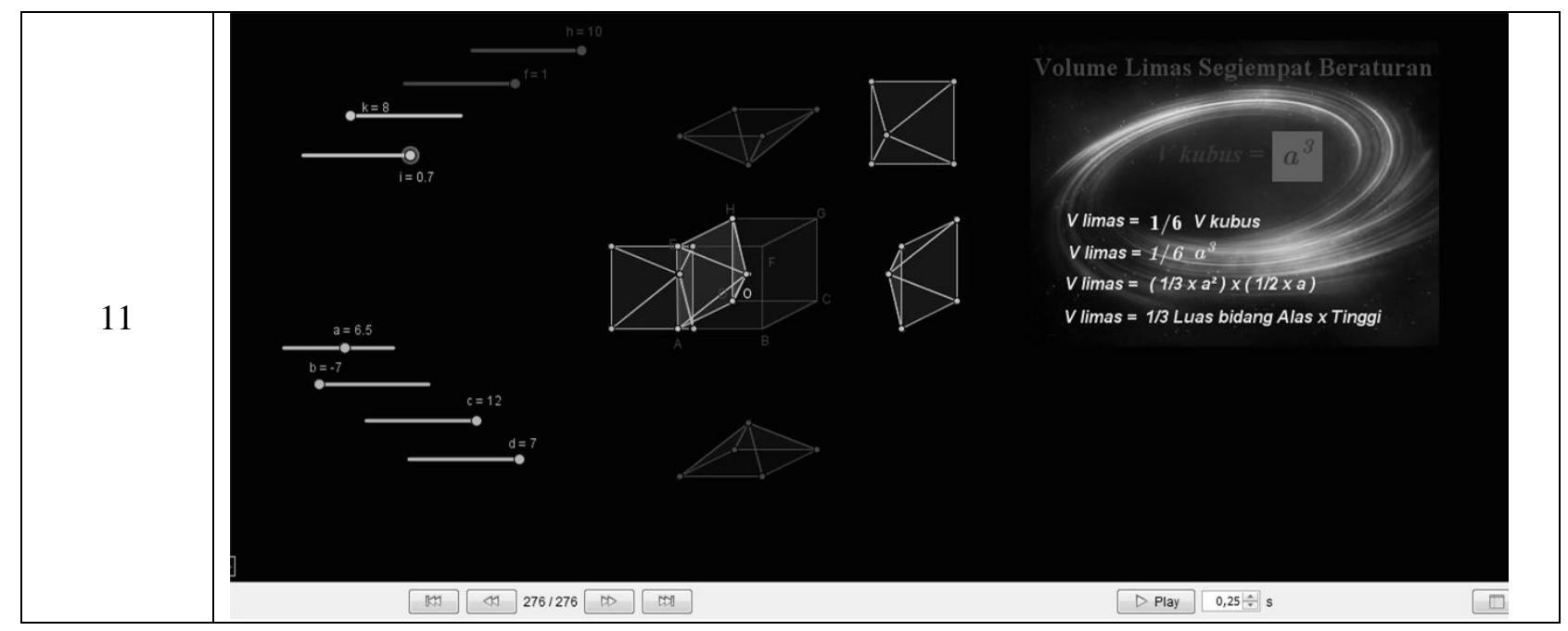

Adapun kemampuan mahasiswa dalam membuat bahan ajar dengan perangkat lunak Geogebra dilihat dari penilaian dosen dan penilaian guru, dapat dilihat pada Tabel 2.

Tabel 2. Kemampuan Mahasiswa dalam Membuat Bahan Ajar dengan Perangkat Lunak Geogebra

\begin{tabular}{|c|l|c|c|c|}
\hline \multirow{2}{*}{ No } & \multirow{2}{*}{ Bahan Ajar } & \multicolumn{3}{|c|}{ Penilaian } \\
\cline { 2 - 5 } & & Dosen & Guru & Rata-rata \\
\hline 1 & Kelompok 1 & 80 & 80 & 80 \\
\hline 2 & Kelompok 2 & 90 & 100 & 95 \\
\hline 3 & Kelompok 3 & 60 & 84 & 72 \\
\hline 4 & Kelompok 4 & 100 & 72 & 86 \\
\hline 5 & Kelompok 5 & 80 & 84 & 82 \\
\hline 6 & Kelompok 6 & 70 & 71 & 70 \\
\hline 7 & Kelompok 7 & 80 & 72 & 76 \\
\hline 8 & Kelompok 8 & 80 & 89 & 85 \\
\hline 9 & Kelompok 9 & 60 & 76 & 68 \\
\hline 10 & Kelompok 10 & 80 & 89 & 85 \\
\hline 11 & Kelompok 11 & 80 & 78 & 79 \\
\hline 12 & Kelompok 12 & 70 & 71 & 70 \\
\hline 13 & Kelompok 13 & 70 & 80 & 75 \\
\hline 14 & Kelompok 14 & 70 & 82 & 76 \\
\hline 15 & Kelompok 15 & 80 & 78 & 79 \\
\hline & Rata-rata & 77 & 80 & 78 \\
\hline & Standar Deviasi & 10,47 & 8,06 & 7,32 \\
\hline
\end{tabular}

Berdasarkan Tabel 2. rata-rata kemampuan mahasiswa dalam membuat bahan ajar dengan perangkat lunak Geogebra dari penilaian dosen adalah 77 atau berada dikategori tinggi dengan standar deviasi 10,47 . Kemudian rata-rata kemampuan mahasiswa dalam membuat bahan ajar dengan perangkat lunak Geogebra dari penilaian guru adalah 80 atau berada dikategori tinggi dengan standar deviasi 8,06. Adapun rata-rata dari penilaian dosen dan guru adalah 78 dan merupakan termasuk kategori tinggi juga dengan standar deviasi 7,32.

Selanjutnya untuk melihat kemampuan mahasiswa berdasarkan aspek yang dinilai oleh guru, diuraikan dalam Tabel 3 berikut, 
Tabel 3 Penilaian Guru

\begin{tabular}{|c|c|c|}
\hline No & Aspek yang Dinilai & Rata-Rata \\
\hline 1 & Pemilihan jenis dan ukuran font & 79 \\
\hline 2 & Pemilihan Komposisi warna & 84 \\
\hline 3 & Gambar & 83 \\
\hline 4 & Animasi & 76 \\
\hline 5 & Tampilan layar & 83 \\
\hline 6 & Kejelasan istilah & 81 \\
\hline 7 & Penggunaan bahasa & 84 \\
\hline 8 & Konsistensi luncuran & 75 \\
\hline 9 & Kejelasan petunjuk penggunaan & 77 \\
\hline 10 & Kemudahan penggunaan & 81 \\
\hline 11 & Efesiensi penggunaan layar & 76 \\
\hline 12 & Efesiensi teks & 77 \\
\hline 13 & Kejelasan visual & 81 \\
\hline 14 & Kejelasan rumusan kompetensi & 80 \\
\hline 15 & Ketepatan materi & 79 \\
\hline 16 & Kejelasan uraian materi & 85 \\
\hline 17 & Kesesuaian dengan tujuan pembelajaran & 84 \\
\hline
\end{tabular}

Berdasarkan Tabel 3. di atas bisa dilihat bahwasanya nilai kemampuan mahasiswa lebih besar dari 75 dan di bawah 90 artinya masuk dalam kategori tinggi di setiap aspek yang dinilai.

Selanjutnya berdasarkan pedoman desain yang dinilai oleh dosen, persentase bahan ajar yang mengacu pada pedoman desain dapat dilihat pada Tabel 3. berikut,

Tabel 4. Penilaian Dosen

\begin{tabular}{|l|l|c|}
\hline No & \multicolumn{1}{|c|}{ Pedoman Desain } & Persentase \\
\hline 1 & Menghindari Scrolling & 100 \\
\hline 2 & Penjelasan Singkat & 87 \\
\hline 3 & Memuat Pertanyaan atau Tugas & 20 \\
\hline 4 & Menghindari Gangguan & 100 \\
\hline 5 & Interaktif & 93 \\
\hline 6 & Mudah digunakan & 100 \\
\hline
\end{tabular}




\begin{tabular}{|l|l|c|}
\hline 7 & Ukuran Cukup Besar dan Cukup Satu Layar & 100 \\
\hline 8 & Menggunakan Teks Dinamis & 47 \\
\hline 9 & Tampilan Memuat Semua Label dan Informasi Penting & 100 \\
\hline 10 & Pertanyaan atau Tugas Spesifik & 20 \\
\hline
\end{tabular}


Beradasarkan tabel di atas bahan ajar yang mencatumkan pertanyaan dan tugas hanya $20 \%$ yaitu sangat rendah dan yang menggunakan teks dinamis hanya $47 \%$ yaitu rendah. Selain dari dua pedoman tadi masuk dalam kategori tinggi dan sangat tinggi.

\section{Kesimpulan Dan Saran}

Kemampuan mahasiswa program studi pendidikan matematika dalam membuat bahan ajar dengan perangkat lunak Geogebra melalui pembelajaran berbasis proyek nilai 78 dan mengindikasikan bahwa Kemampuan mahasiswa program studi pendidikan matematika dalam membuat bahan ajar dengan perangkat lunak Geogebrapada kategori tinggi.

Mahasiswa program studi pendidikan matematika sebagai calon guru matematika didorong untuk mengembangkan kemampuan dalam membuat bahan ajar dengan media komputer khususnya perangkat lunak Geogebra yang inovatif, kreatif, efektif, efisien dan kontekstual

\section{Daftar Pustaka}

(2014). What is GeoGebra.

Tersedia:http://www.GeoGebra.org/cms lin/info. [23 Maret 2014].

Departemen Pendidikan Nasional. (2013). Salinan Lampiran Permendikbud No. 65 Tahun 2013 Tentang Standar Proses. Jakarta.

Departemen Pendidikan Nasional. (2014). Pedoman Mata Pelajaran Matematika. Jakarta.

Hamdani.(2011). Strategi Belajar Mengajar, Bandung: CV Pustaka Setia.

Hermawan, Asep H. dkk. (2010). Pengembangan Bahan Ajar. Tersedia: http://file.upi.edu/Direktori/FIP/JUR. KURIKULUM_DAN_TEK._PENDIDIK AN/194601291981012PERMASIH/PENGEMBANGAN_BAHA N_AJAR.pdf. [2 Juni 2015]

Hohenwarter, M. \& Fuchs, K. (2004). Combination of Dynamic Geometry,
Algebra, and Calculus in the Software System Geogebra.

Tersedia:www.geogebra.org/publicatio ns/pecs_2004.pdf. [23 Maret 2014].

Judith and Hohenwarter. (2013). Introduction to Geogebra. Tersedia: www.geogebra.org. [April 2015]

Kusumah, Yaya S. (2011). Pembelajaran Berbasis Teknologi Informasi (It-Based Teaching). Makalah Jurusan Pendidkan Matematika FPMIPA Universitas Pendidikan Indonesia.

Mahmudi, Ali. (2011).Pemanfaatan GeoGebra dalam Pembelajaran Matematika. Tesedia: https://www.academia.edu/2137476/Pe manfaatan_GeoGebra_dalam_Pembelaj aran_Matematika. [23 Maret 2014].

Pemerintah Republik Indonesia.(2003). Undang-Undang Republik Indonesia Nomor 20 Tahun 2003 Tentang Sistem Pendidikan Nasional. Jakarta.

Prastowo, Andi. (2014). Panduan Kreatif Membuat Bahan Ajar Inovatif. Yogyakarta:Diva Press.

Purwanto 2004 Pengembangan Materi ELearning di PUSTEKKOM. Makalah disajikan dalam Seminar Nasional : “ Implementasi E-Learning di Indonesia, Prospek dan Tantangan bagi Sistem Pendidikan Tinggi Nasional". Bandung : IAIN, BPPT, dan STTMI

Rahmi, Aida dan Harmi Hendra. (2013). Pengembangan Bahan Ajar. MI Curup: Lp2 STAIN Curup.

Sahid. (2010). Aktivitas Belajar Persamaan Lingkaran dan Garis Singgungnya dengan Software GeoGebra. Tersedia: http://staff.uny.ac.id/sites/default/files/t mp/10_GeoGebra4Lingkaran.pdf. [23 Maret 2014]

Suherman, Erman dan Sukjaya, Yaya. 1990. Evaluasi Pendidikan Matematika. Bandung: Wijayakusumah.

Sutopo, H.A. 2003. Multimedia Interaktif dengan Flash. Yogyakarta : Graha Ilmu 